\title{
Variability of fluxes of particulate material in a submarine cave with chemolithoautotrophic inputs of organic carbon
}

\author{
Laura Airoldi*, Francesco Cinelli \\ Dipartimento di Scienze dell'Ambiente e del Territorio, Università di Pisa, Via A. Volta 6, I-56126 Pisa, Italy
}

\begin{abstract}
The composition and vertical fluxes of particulate material were studied in February, May and October 1994 and in February 1995 in a submarine cave (Grotta Azzurra, Capo Palinuro, southwestern coast of Italy) influenced by the presence in its innermost dark region (Snow Hall) of hot sulphurous springs supporting dense mats of chemolithoautotrophic bacteria. A multifactorial sampling design was used to specifically address whether there were differences in the quantity and quality of particles sedimenting at different sites within Snow Hall and in the outer non sulphurous region of the cave (Central Hall), and whether patterns were consistent over time. Materlal collected in sediment traps was analysed to quantify the content of coarse particles, total particulate material, particulate organic carbon, particulate organic nitrogen, chlorophyll $a$, phaeopigments, total carbohydrates, total proteins and total lipids. Microscopic analyses were also carried out in order to characterisc coarse and particulate material. The most abundant recognisable particles in the traps were faecal pellets, Posido$n 1 a$ and algal debris and fragments of organisms living on the vault of the cave, while a great proportion of coarse material consisted of generally unidentifiable amorphous aggregates. Both the magnitude of flux and nature of the sedimented matenal were heterogeneous. Such variability was especially evident on a small spatial scale. Significant variation among sites sampled in each region was detected during each sampling period for the majority of the compounds that were analysed. Conversely, differences between the 2 regions were generally low and were not consistent through time. A clear spatial trend emerged only for chloropigments, whose sedimentation rates consistently decreased from Central Hall to Snow Hall. In contrast to the general paradigm of caves as simplified oligotrophic ecosystems driven by their proximity to an outside source of energy, the observed patterns suggest that vertical fluxes of particulate material in this peculiar environment are influenced by local processes acting on a small spatial scale within the cave. It is also indicated that bacterial chemosynthetic production supplies fresh organic material to the cave benthos in the form of sinking particles.
\end{abstract}

KEY WORDS: Spatial variability - Particulate material - Fluxes - Sources - Biochemical composition Sediment traps Submarine caves Chemosynthesis

\section{INTRODUCTION}

Knowledge of the composition and flux of sinking particulate material is central to identifying the origins, pathways and fates of constituent substances and provides insight into the ecological role of particles in marine environments (Smetaceck 1984, Valiela 1984, Lee \& Wakeham 1988). In recent years, considerable

\footnotetext{
•E-mail: lairoldi@discat.unipi.it
}

improvement of sediment trap designs and techniques (Bloesh \& Burns 1980, Blomqvist \& Hákanson 1981) has facilitated quantification and characterisation of the fluxes of sedimenting particles in many oceanic (Honjo 1980, Deuser et al. 1981, Fellows et al. 1981, Fowler \& Knauer 1986) and coastal areas (Peinert et al. 1982. Wassmann 1985, 1991, Bavestrello et al. 1991. Puskaric et al. 1992). Results from these studies have produced evidence that the quantity and quality of sinking particulate material reaching the sea floor are highly variable in space and time, reflecting the com- 
plex hydrographical and biological processes occurring in the water column and at the water-sediment interface. This variability is assumed to be one of the major factors influencing the distribution, biomass and metabolic activity of benthic communities in many different habitats (Mills 1975, Graf et al. 1982, Stewart 1983, Smetaceck 1984. Yap 1991, Pfannkuche 1993, Airoldi et al. 1996). Measuring spatial and temporal patterns in the flux of sinking particles contributes, therefore, to an understanding of the structure and functioning of marine ecosystems as well as of the supply of food and energy to the benthos.

Submarine caves are common along the coasts of the Mediterranean sea, especially where the predominating limestone rock undergoes erosion and karst formation, and may be considered a typical feature of this basin (Riedl 1966). Their distinctive geological, hydrodynamical and ecological characteristics, such as absence of light, limited water flows, low fluxes of organic material and occurrence of sharp physical, chemical and energy gradients, make them unique marine environments within coastal ecosystems (Laborel \& Vacelet 1959, Ott \& Svoboda 1976, Harmelin et al. 1985). Moreover, faunal and ecological similarities with deep sea habitats (Vacelet et al. 1994) contribute to the interest in submarine caves. This interest is reflected by an extensive and diverse body of literature (True 1970, Cinelli et al. 1977, Gili et al. 1986, Balduzzi et al. 1989, Bibiloni et al. 1989, Zabala et al. 1989, ISSD 1994). However few studies have examined the composition and cycling of particulate material in Mediterranean caves (Fichez 1990a, 1991a, b, c), and only one has included measurements of sedimentation rates (Fichez 1990b).

Dark caves are devoid of autochthonous phytoplanktonic production because of the absence of light, and the heterotrophs subsist on supplies of organic material advected from the open sea (Fichez 1990a, 1991b). Due to low levels of hydrodynamism and reduced mixing of the water masses, particles entering the caves via water exchanges rapidly sink to the surface of the sediments (Fichez 1990b, Garrabou \& Flos 1995). Sedimentation, together with progressive filtering off and degradation of particulate organic material, typically results in a progressive impoverishment of trophic resources, which is thought to be responsible for severe reductions of organism biomass observed in the innermost parts of dark single-entrance caves (Pérès \& Picard 1949, Laborel \& Vacelet 1959, Gili et al. 1986, Balduzzi et al. 1989, Fichez 1990b, Palau et al. 1991. Garrabou \& Flos 1995). However, recent multidisciplinary investigations on some caves with sulphide inputs from submarine hot springs have shown that in these unique environments sulphur-oxidizing bacteria act as primary producers fixing carbon through chemosyn- thesis (Mattison et al. 1996, Southward et al. 1996). Such autochthonous bacterial production may locally enrich invertebrate abundance, supplying fresh organic material in addition to the pelagic flux from outside primary production (Southward et al. 1996, L. Airoldi \& F. Cinelli unpubl.).

The aim of the present work was to study the spatial variability in the composition and vertical fluxes of particulate material in a Mediterranean shallow-water submarine cave influenced by sulphur springs. The amount and the biochemical composition of sedimenting particles were studied by means of sediment-trap deployments. A multifactorial sampling design was used to specifically address whether there were differences in the quantity and quality of particles sedimenting in different areas of the cave and whether the observed patterns were consistent through time. The research was carried out in tandem with measurements of the concentration and composition of suspended particulate material (Airoldi \& Cinelli unpubl.) and experimental investigations on factors affecting patterns of distribution of the biological communities (Benedetti-Cecchi et al. in press).

\section{MATERIAL AND METHODS}

Site description. The study was carried out from February 1994 to February 1995 in Grotta Azzurra cave, on the southwestern coast of Italy. The cave opens in the limestone massif of Capo Palinuro and may be separated into 2 topographically distinct regions with different characteristics (Fig. 1A). The first outer region (Central Hall) is a wide double-entrance chamber that reaches a maximum depth of about $30 \mathrm{~m}$; here a faint light is still present, and currents create water exchanges with the open sea. A smaller, shal lower (about $15 \mathrm{~m}$ ), inner region (Snow Hall) opens on the south side of Central Hall with respect to the main entrance; this part of the cave is completely dark, has a reduced hydrodynamic regime $\left(<10 \mathrm{~cm} \mathrm{~s}^{-1}\right.$; D. Stüben unpubl.) and is characterised by the presence of hot sulphur springs that arise from fissures in the floor and in the sides. The warm $\left(23\right.$ to $24^{\circ} \mathrm{C}$ ) sulphurous water stratifies above the ambient cooler $\left(14\right.$ to $\left.20^{\circ} \mathrm{C}\right)$ sea water just below the vault (Fig. 1B), forming a sharp boundary at about $9 \mathrm{~m}$ depth (a detailed description of the geochemical composition of the water masses of Grotta Azzurra cave is reported by Stüben et al. 1996 and Fitzsimons \& Dando 1996). Dense mats of sulphur oxidising bacteria (including Beggiatod-like filamentous colonies up to $100 \mu \mathrm{m}$ in diameter) line the rocky walls and the vault above the chemocline and act as primary producers, fixing $\mathrm{CO}_{2}$ by means of the autotrophic enzyme ribulosebisphosphate carboxylase 
(Mattison \& Dando 1994, Mattison et al. 1996, Southward et al. 1996). Below the chemocline, rich faunal assemblages occur on both the walls (sponges and cnidarians) and the sediment floor (bivalves, ophiurids, tubicolous polychaetes). Other information on the distribution of benthic fauna in Grotta Azzura cave may be found in Akoumianaki \& Huges (1996), Southward et al. (1996) and in L. Benedetti-Cecchi, L. Airoldi, M. Abbiati \& F. Cinelli (unpubl.).

Sampling. The null hypothesis of no differences in the quantity and quality of particulate material sedimenting in Central Hall and in Snow Hall was experimentally investigated by comparing the fluxes measured at different sites in each of these 2 regions. Sedimentation rates of different compounds were measured using 6 trap systems, each consisting of 4 polypropylene cylindrical vessels positioned with their mouths at $1.5 \mathrm{~m}$ above the sea floor. Each vessel had a diameter of $51 \mathrm{~mm}$ and a height of $200 \mathrm{~mm}$ (aspect ratio: 3.9) and was fixed with rubber bands onto a cylindrical PVC tube (diameter $60 \mathrm{~mm}$, height $150 \mathrm{~mm}$ ) mounted at one of the 4 extremities of a stainless steel, cross shaped frame anchored to the bottom and made vertically stable in the water column by a buoyant float. The sediment traps were deployed at 6 sites ( 3 in Central Hall and 3 in Snow Hall; Fig. 1A) selected at random from 12 sites with similar topographic bottom characteristics, which in all cases consisted of rocky boulders covered by a thin layer of sediment and had a depth of about $15 \mathrm{~m}$ (location of sediment traps in depressions of the floor with accumulations of muddy sediment was deliberately avoided to prevent instability of traps and excessive resuspension of bottom sediments). Therefore, for each region (Central Hall vs Snow Hall) there were 3 replicated sampling sites, and for each site 4 replicated collection vessels.

The experiments were conducted in February, May and October 1994 and in February 1995 in order to verify whether patterns observed were consistent through different sampling periods. During these periods the traps were deployed for intervals of 7,11 , 9 and 7 d respectively. Deployment and retrieval of the vessels were carried out by SCUBA diving; vessels were closed with Parafilm and plastic stoppers before retrieval. In February and May 1994 during the periods of deployment of the traps some field activities were carried out in the cave by other divers involved in the same multidisciplinary research: on such occasions the vessels were closed with plastic stoppers for the entire length of the dives (about $70 \mathrm{~min}$ in order to reduce possible perturbation induced by divers. No preservatives were added, since there is some debate about possible artifacts associated with their use (Knauer et al. 1984, Gundersen \& Wassmann 1990, Lee et al. 1992, Hedges et al. 1993), and possible decay of organic carbon in nonpoisoned traps generally affects measured fluxes only when traps are deployed in the field for intervals longer than those in present study (Gundersen \& Wassmann 1990). The samples were immediately transported to the laboratory and stored in a cooler 
$\left(-4^{\circ} \mathrm{C}\right)$ until filtration, which was always completed within 20 to $30 \mathrm{~h}$ after retrieval.

Analysis. Material collected in each trap was passed through $200 \mu \mathrm{m}$ mesh to separate the coarse particles retained on the mesh (hereafter coarse material. CM) from the finer ones (hereafter particulate material), and the abundance and composition of both components was then quantitatively assessed.

The CM from 1 trap from each site was picked up from the mesh and preserved with buffered formalin $(5 \%)$ for microscopic analysis. A grid with 50 equally spaced dots was placed below the Petri dish where the material was being examined, and contacts with particles were counted under a stereomicroscope (Airoldi et al. 1996). The abundance of different kinds of particles was expressed as the percentage over the total number of contacts. The amount of $\mathrm{CM}$ from the remaining 3 traps at each site was determined gravimetrically on preweighed meshes (Krey 1964). The material was rinsed with distilled water to remove salts and dried at $60^{\circ} \mathrm{C}$ for $48 \mathrm{~h}$ before weighing

The smaller particles passing through the mesh were resuspended in $1 \mathrm{l}$ of filtered cave seawater (Sartorius SM 113, $0.2 \mu \mathrm{m}$ ) and kept homogeneous by agitation on a magnetic stirrer. Aliquots were withdrawn by pipetting from the suspension and filtered through precombusted $\left(450^{\circ} \mathrm{C}, 3 \mathrm{~h}\right) 25 \mathrm{~mm}$ Whatman GF/F glass microfibre filters for analysis of total (TPM) and inorganic (PIM) particulate material, particulate organic carbon (POC) and nitrogen (PON), chlorophyll a (chl a) and phaeopigments (phaeo), total carbohydrates (TCH), proteins (TPR) and lipids (TLI). Each measurement was replicated at least twice. Blank filters for all the analyses were prepared on each collection date and treated in the same manner as the samples, and corrections were made for values from these blanks. Filters were stored in darkness at $-20^{\circ} \mathrm{C}$ until the analyses were done. A small aliquot $(10 \mathrm{ml})$ was preserved with buffered formalin $(5 \%)$ for qualitative microscopic analysis.

TPM was determined gravimetrically on preweighed filters (Krey 1964). Filters with retained material were rinsed with distilled water to remove salts, dried at $60^{\circ} \mathrm{C}$ for $24 \mathrm{~h}$, allowed to cool in a dessicator and weighed on an Ohaus balance (mod. Galaxy TM100) to a precision of $10^{-4} \mathrm{~g}$ in the presence of silica gel. Filters were then ignited at $450^{\circ} \mathrm{C}$ for $3 \mathrm{~h}$ and reweighed after cooling in order to determine the content of PIM (Dean 1974).

$\mathrm{POC}$ and PON were analysed with a CHN analyser (Carlo Erba Model 1106). To remove any carbonates, filters were treated with fumes of $\mathrm{HCl}$ for $5 \mathrm{~h}$ and dried prior to andlysis (Hedges \& Stern 1984).

Chl a and phaeo were extracted with $90 \%$ acetone (24 h at $4^{\circ} \mathrm{C}$ in darkness) and determined spectropho- tometrically before and after treatment with dilute $\mathrm{HCl}$ (Strickland \& Parsons 1972). The total amount of chloropigments (pigm) was then calculated as their sum. In October 1994, fluxes of chloropigments were very low, and on 3 occasions the amount of chl a retained by the filters was below the limits of sensitivity of the analytical method. In such cases, in order to be able to calculate POC:chl a ratios (otherwise equal to $\infty)$, the flux of chl a was arbitrarily assigned a value of $0.02 \mathrm{mg} \mathrm{m}^{-2} \mathrm{~d}^{-1}$, a value slightly lower than the lowest measurement during the same period $10.03 \mathrm{mg}$ $\mathrm{m}^{-2} \mathrm{~d}^{-1}$ ).

TCH, TPR and TLI were determined colorimetrically. Carbohydrates were titrated by the phenol-sulphuric acid method of Dubois et al. (1956) after extraction in distilled water (Moal et al. 1985) and expressed as glucose equivalents. Proteins were extracted with distilled water (Moal et al. 1985), titrated with the Folin phenol reagent method (Lowry et al. 1951) and expressed as albumin equivalents. Lipids were extracted with chloroform according to the method of Blight \& Dyer (1959), titrated by the sulphuric acid method of Marsh \& Weinstein (1966) and expressed as tripalmitic acid equivalents.

Variations in sedimentation rates of different compounds were analysed using a 3-way mixed model ANOVA, with time (February vs May vs October 1994 vs February 1995) and region (Central Hall vs Snow Hall) as fixed factors and sites as the random variable nested in region. Since vessels were attached in a regular pattern to the same frame, we may not exclude the possibility that fluxes measured by replicated traps within each site were non-independent. If some positive correlation occurred, then the outcome of the statistical tests for differences among sites and time $\times$ sites interactions might have been affected by an increased probability of. Type I error (Underwood 1981). Before running the analyses, the homogeneity of variances was examined using Cochran's C-test (Winer 1971). $\mathrm{CM}$ and the ratios between different biochemical compounds were log transformed. Student-Newman-Keuls tests were used for a posteriori multiple comparisons of means.

\section{RESULTS}

\section{Spatial and temporal variability}

Mean vertical fluxes of compounds of sedimenting particulate material measured both in Central Hall and in Snow Hall displayed considerable small-scale spatial variability (Fig. 2). Significant differences among sites within regions were, in fact, detected for TPM, PIM, POC, PON, TPR and TLI for all the sampling 


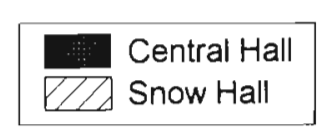

Fig. 2. Sedimentation rates of coarse material (CM), total particulate material (TPM), particulate inorganic material (PIM), particulate organic carbon (POC), particulate organic nitrogen (PON), chlorophyll a (Chl a), phaeopigments (Phaeo), total carbohydrates (TCH), total proteins (TPR) and total lipids (TLI) measured in different regions (Central Hall vs Snow Hall) of Grotta Azzurra cave during February, May and October 1994 and February 1995 Three random sites were replicated for each region. Data are means $+1 \mathrm{SD}$ ( $\mathrm{n}=3$ for $\mathrm{CM}$ and 4 for all the other cases)
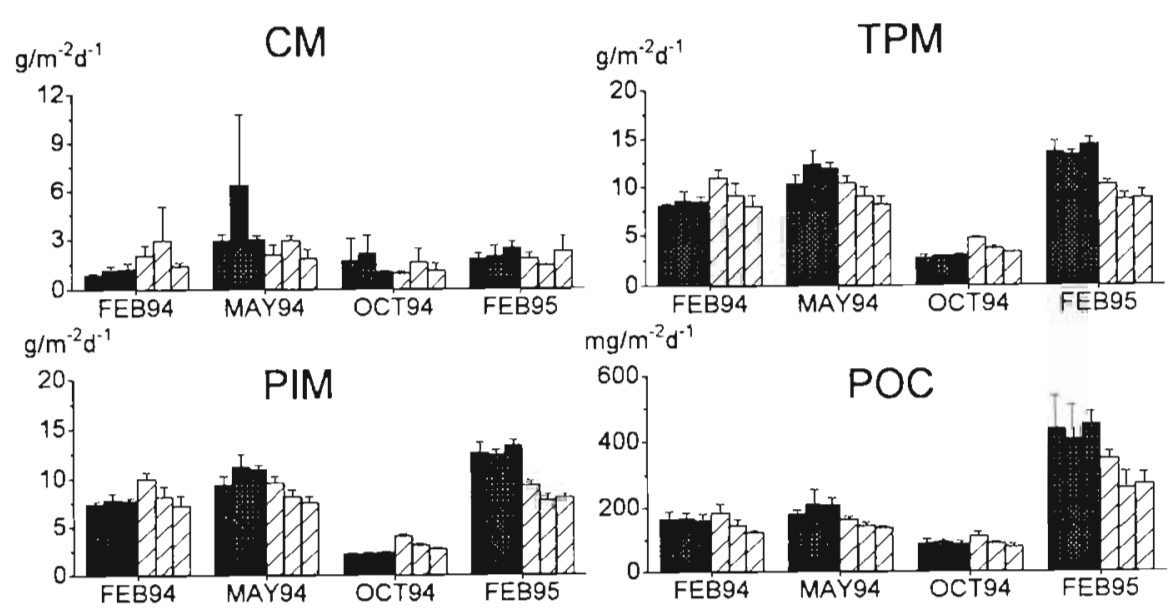

$\mathrm{mg} / \mathrm{m}^{-2} \mathrm{~d}^{-1}$
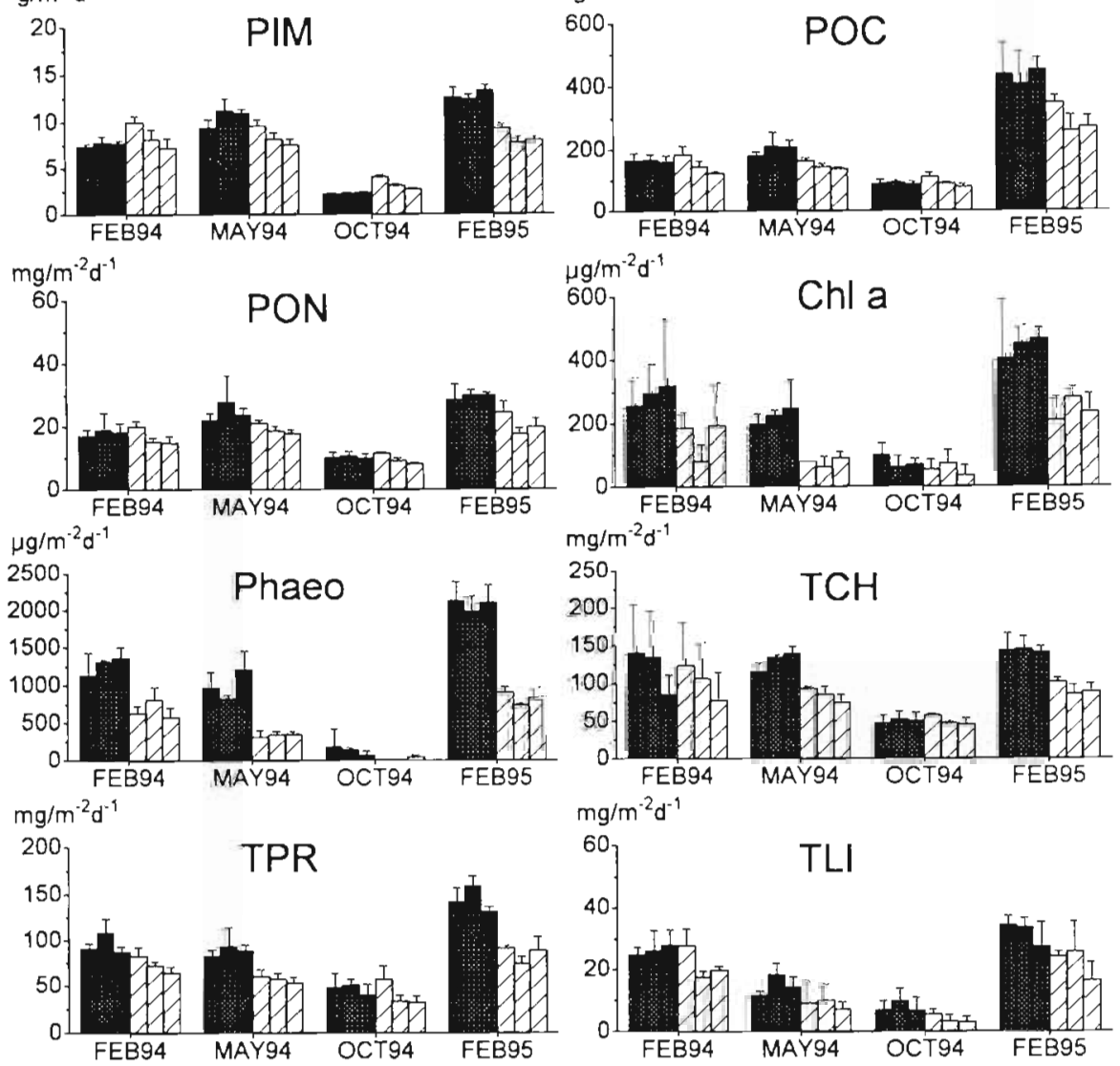

$\mathrm{mg} / \mathrm{m}^{-2} \mathrm{~d}^{-1}$

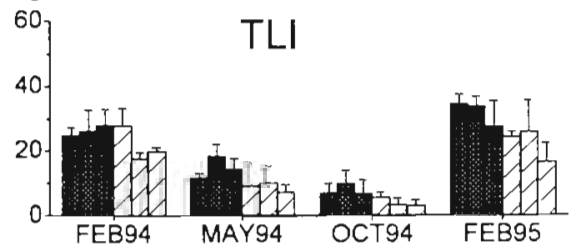

periods (Tables $1 \& 2$ ). Spatial variations among sites were also detected for phaeo, but these were not consistent through time, as indicated by the significant interaction time $\times$ site (region).

Variations between Central Hall and Snow Hall were highly dependent on the timing of sampling (Fig. 2): a significant region $\times$ time interaction was, in fact, observed for all the constituents that have been analysed with the exception of TLI (Tables 1 \& 2). Overall (and especially in October 1994), the differences between the 2 regions of the cave were small, and/or no consistent spatial patterns were discernible. A clear trend was evident only for chl a and phaeo, whose vertical fluxes sharply decreased from Central Hall to Snow Hall during most of the research (Fig. 2, Table 1).

\section{Nature and quality of sedimented particles}

Microscopic analysis revealed that most of the CM found in the sediment traps from both Central Hall and Snow Hall consisted of amorphous aggregates, faecal pellets and inorganic detritus, such as spicules of sponges and fragments of the calcareous skeletons of cnidarians and other benthic organisms living on the vault and on the walls of Grotta Azzurra cave (Fig. 3). Sometimes large Beggiatoa-like bacterial filaments could be identified inside the aggregates, expecially in traps from Snow Hall. Eggs, larvae and a variety of juvenile benthic invertebrates such as crustaceans, clams, ophiurids and polychaetes were sporadically present, being more abundant in May 1994 in traps from Central Hall. Coarse particles clearly originating 
Table 1. ANOVA table showing the effects of Time (Feb 94 vs May 94 vs Oct 94 vs Feb 95), Region (Snow Hall vs Central Hall) and Site on sedimentation rates of coarse material (CM), total particulate material (TPM), particulate inorganic material (PIM), particulate organic carbon (POC), particulate organic nitrogen (PON), chlorophyll a (chl a) and phaeopigments (phaeo) in Grotta Azzurra cave. Time and Region are fixed factors, while Site represents a random variable nested in Region. Log transformation was required for CM. Variances were homogeneous after Cochran's $C$-tests. Signuficant $p$ values $(p<0.05)$ are shown in bold type

\begin{tabular}{|c|c|c|c|c|c|c|c|}
\hline \multicolumn{2}{|c|}{ Source of variation } & \multirow{3}{*}{$\begin{array}{r}\text { df } \\
3\end{array}$} & \multirow{3}{*}{$\begin{array}{c}\text { MS } \\
2.319\end{array}$} & \multirow{3}{*}{$\begin{array}{r}F \\
13.01\end{array}$} & \multirow{3}{*}{$\begin{array}{c}p \\
0.0004\end{array}$} & \multicolumn{2}{|c|}{ SNK test } \\
\hline $\mathrm{CM}$ & & & & & & Time & Region \\
\hline Time & $(=\mathrm{T})$ & & & & & & \\
\hline Region & $(=\mathrm{R})$ & 1 & 0.111 & 0.41 & 0.558 & Feb 94 & Snow Hall $>$ Central Hall \\
\hline $\mathrm{T} \times \mathrm{R}$ & & 3 & 0.989 & 5.54 & 0.012 & May 94 & Snow Hall < Central Hall \\
\hline Site $(R)$ & $(=\mathrm{S})$ & 4 & 0.273 & 2.02 & 0.106 & Oct 94 & Snow Hall = Central Hall \\
\hline$T \times S(R)$ & & 12 & 0.178 & 1.32 & 0.239 & Feb 95 & Snow Hall = Central Hall \\
\hline Error & & 48 & 0.135 & & & & \\
\hline TPM & & & & & & Time & Region \\
\hline Time & $(=\mathrm{T})$ & 3 & 304.8 & 321.04 & 0.0001 & & \\
\hline Region & $(=R)$ & 1 & 35.86 & 3.71 & 0.127 & Feb 94 & Snow Hall > Central Hall \\
\hline $\mathrm{T} \times \mathrm{R}$ & & 3 & 43.5 & 45.82 & 0.0001 & May 94 & Snow Hall $<$ Central Hall \\
\hline Site $(R)$ & $(=S)$ & 4 & 9.68 & 15.98 & 0.0001 & Oct 94 & Snow Hall $>$ Central Hall \\
\hline$T \times S(R)$ & & 12 & 0.95 & 1.57 & 0.121 & Feb 95 & Snow Hall < Central Hall \\
\hline Error & & 72 & 0.61 & & & & \\
\hline PIM & & & & & & Time & Region \\
\hline Time & $(=\mathrm{T})$ & 3 & 281.28 & 342.3 & 0.0001 & & \\
\hline Region & $(=\mathrm{R})$ & 1 & 31.63 & 3.63 & 0.13 & Feb 94 & Snow Hall > Central Hall \\
\hline $\mathrm{T} \times \mathrm{R}$ & & 3 & 40.22 & 48.94 & 0.0001 & May 94 & Snow Hall < Central Hall \\
\hline Site (R) & $(=\mathrm{S})$ & 4 & 8.71 & 18.92 & 0.0001 & Oct 94 & Snow Hall > Central Hall \\
\hline$T \times S(R)$ & & 12 & 0.82 & 1.78 & 0.067 & Feb 95 & Snow Hall < Central Hall \\
\hline Error & & 72 & 0.46 & & & & \\
\hline POC & & & & & & Time & Region \\
\hline Time & $(=\mathrm{T})$ & 3 & 327335 & 290.36 & 0.0001 & & \\
\hline Region & $(=\mathrm{R})$ & 1 & 60357 & 10.04 & 0.034 & Feb 94 & Snow Hall = Central Hall \\
\hline $\mathrm{T} \times \mathrm{R}$ & & 3 & 24561 & 21.79 & 0.0001 & May 94 & Snow Hall < Central Hall \\
\hline Site $(R)$ & $(=S)$ & 4 & 6015 & 3.81 & 0.007 & Oct 94 & Snow Hall = Central Hall \\
\hline $\mathrm{T} \times \mathrm{S}(\mathrm{R})$ & & 12 & 1.127 & 0.71 & 0.733 & Feb 95 & Snow Hall < Central Hall \\
\hline Error & & 72 & 1580 & & & & \\
\hline PON & & & & & & Time & Region \\
\hline Time & $(=\mathrm{T})$ & 3 & 1007 & 166.3 & 0.0001 & & \\
\hline Region & $(=\mathrm{R})$ & 1 & 387 & 6.74 & 0.06 & Feb 94 & Snow Hall = Central Hall \\
\hline $\mathrm{T} \times \mathrm{R}$ & & 3 & 87 & 14.37 & 0.0003 & May 94 & Snow Hall < Central Hall \\
\hline Site (R) & $(=S)$ & 4 & 57.4 & 6.45 & 0.0002 & Oct 94 & Snow Hall = Central Hall \\
\hline $\mathrm{T} \times \mathrm{S}(\mathrm{R})$ & & 12 & 6.05 & 0.68 & 0.765 & Feb 95 & Snow Hall < Central Hall \\
\hline Error & & 72 & 8.9 & & & & \\
\hline Chl a & & & & & & Time & Region \\
\hline Time & $(=\mathrm{T})$ & 3 & 0.327 & 65.56 & 0.0001 & & \\
\hline Region & $(=\mathrm{R})$ & 1 & 0.387 & 128.03 & 0.0003 & Feb 94 & Snow Hall < Centra I Hall \\
\hline $\mathrm{T} \times \mathrm{R}$ & & 3 & 0.033 & 6.62 & 0.0069 & May 94 & Snow Hall < Central Hall \\
\hline Site $(R)$ & $(=\mathrm{S})$ & 4 & 0.003 & 0.46 & 0.767 & Oct 94 & Snow Hall = Central Hall \\
\hline $\mathrm{T} \times \mathrm{S}(\mathrm{R})$ & & 12 & 0.005 & 0.76 & 0.692 & Feb 95 & Snow Hall < Central Hall \\
\hline Error & & 72 & 0.007 & & & & \\
\hline Phaeo & & & & & & Time & Region \\
\hline Time & $(=\mathrm{T})$ & 3 & 7.88 & 169.21 & 0.0001 & & \\
\hline Region & $(=\mathrm{R})$ & 1 & 10.17 & 308.35 & 0.0001 & Feb 94 & Snow Hall < Central Hall \\
\hline $\mathrm{T} \times \mathrm{R}$ & & 3 & 1.3 & 27.99 & 0.0001 & May 94 & Snow Hall < Central Hall \\
\hline Site $(R)$ & $(=\mathrm{S})$ & 4 & 0.033 & 1.41 & 0.241 & Oct 94 & Snow Hall < Central Hall \\
\hline $\mathrm{T} \times \mathrm{S}(\mathrm{R})$ & & 12 & 0.047 & 1.98 & 0.038 & Feb 95 & Snow Hall < Central Hall \\
\hline Error & & 72 & 0.023 & & & & \\
\hline
\end{tabular}

from outside the cave were found in traps from both regions during all the sampling periods. These were mainly Posidonia and algal debris. Charcoal fragments, probably originating from coastal vegetation fires, were occasionally also found in October 1994 and February 1995

The TPM also consisted mainly of small amorphous aggregates. Recognisable structures were chiefly 
Table 2. ANOVA table showing the effects of Time (Feb 94 vs May 94 vs Oct 94 vs Feb 95), Region (Snow Hall vs Central Hall) and Site on sedimentation rates of total carbohydrates (TCH), total proteins (TPR), total lipids (TLI) and food material and on values of the food index and amount of food energy in Grotta Azzurra cave. Time and Region are fixed factors, while Site represents a random variable nested in Region. Food index and food energy were log transformed. Variances were homogeneous after Cochran's $C$-test. Significant $p$ values $(p<0.05)$ are shown in bold type

\begin{tabular}{|c|c|c|c|c|c|c|c|}
\hline \multicolumn{2}{|c|}{ Source of variation } & \multirow[t]{2}{*}{ df } & \multirow[t]{2}{*}{ MS } & \multirow[t]{2}{*}{$F$} & \multirow[t]{2}{*}{$\mathrm{p}$} & \multicolumn{2}{|c|}{ SNK test } \\
\hline $\mathrm{TCH}$ & & & & & & Time & Region \\
\hline Time & $(=\mathrm{T})$ & 3 & 23131 & 29.92 & 0.0001 & & \\
\hline Region & $(=\mathrm{R})$ & 1 & 19160 & 14.26 & 0.02 & Feb 94 & Snow Hall $=$ Central Hall \\
\hline$T \times R$ & & 3 & 3387 & 4.38 & 0.027 & May 94 & Snow Hall < Central Hall \\
\hline Site (R) & $(=S)$ & 4 & 1344 & 1.71 & 0.157 & $\operatorname{Oct} 94$ & Snow Hall = Central Hall \\
\hline$T \times S(R)$ & & 12 & 773 & 0.98 & 0.471 & Feb 95 & Snow Hall < Central Hall \\
\hline Error & & 72 & 785 & & & & \\
\hline TPR & & & & & & Time & Region \\
\hline Time & $(=\mathrm{T})$ & 3 & 20348 & 131.31 & 0.0001 & & \\
\hline Region & $(=\mathrm{R})$ & 1 & 20628 & 19.2 & 0.012 & Feb 94 & Snow Hall < Central Hall \\
\hline$T \times R$ & & 3 & 3020 & 19.49 & 0.0001 & May 94 & Snow Hall < Central Hall \\
\hline Site $(R)$ & $(=S)$ & 4 & 1075 & 9.36 & 0.0001 & Oct 94 & Snow Hall = Central Hall \\
\hline$T \times S(R)$ & & 12 & 155 & 1.35 & 0.21 & Feb 95 & Snow Hall < Central Hall \\
\hline Error & & 72 & 115 & & & & \\
\hline TLI & & & & & & Time & \\
\hline Time & $(=\mathrm{T})$ & 3 & 2407 & 65.04 & 0.0001 & & \\
\hline Region & $(=\mathrm{R})$ & 1 & 896.3 & 12.64 & 0.02 & Feb $95>$ & $>$ May $94>$ Oct 94 \\
\hline $\mathrm{T} \times \mathrm{R}$ & & 3 & 40.34 & 1.09 & 0.39 & & \\
\hline Site (R) & $(=\mathrm{S})$ & 4 & 70.89 & 3.26 & 0.02 & & \\
\hline$T \times S(R)$ & & 12 & 37.02 & 1.7 & 0.08 & & \\
\hline Error & & 72 & 21.72 & & & & \\
\hline Food mater & & & & & & Time & Region \\
\hline Time & $(=\mathrm{T})$ & 3 & 109320 & 103.7 & 0.0001 & & \\
\hline Region & $(=\mathrm{R})$ & 1 & 97331 & 17.3 & 0.014 & Feb 94 & Snow Hall $=$ Central Hall \\
\hline $\mathrm{T} \times \mathrm{R}$ & & 3 & 13538 & 12.85 & 0.0005 & May 94 & Snow Hall < Central Hall \\
\hline Site (R) & $(=S)$ & 4 & 5614 & 5.49 & 0.0006 & Oct 94 & Snow Hall = Central Hall \\
\hline$T \times S(R)$ & & 12 & 1053 & 1.03 & 0.43 & Feb 95 & Snow Hall $<$ Central Hall \\
\hline Error & & 72 & 1022 & & & & \\
\hline Food mater & I:TPM & & & & & Time & Region \\
\hline Time & $(=\mathrm{T})$ & 3 & 0.9207 & 69.63 & 0.0001 & & \\
\hline Region & $(=\mathrm{R})$ & 1 & 1.4322 & 23.76 & 0.0082 & Feb 94 & Snow Hall < Central Hall \\
\hline $\mathrm{T} \times \mathrm{R}$ & & 3 & 0.1116 & 8.44 & 0.0028 & May 94 & Snow Hall < Central Hall \\
\hline Site (R) & $(=\mathrm{S})$ & 4 & 0.0602 & 1.84 & 0.13 & Oct 94 & Snow Hall < Central Hall \\
\hline $\mathrm{T} \times \mathrm{S}(\mathrm{R})$ & & 12 & 0.0132 & 0.4 & 0.9575 & Feb 95 & Snow Hall = Central Hall \\
\hline Error & & 72 & 0.0327 & & & & \\
\hline Energy & & & & & & Time & Region \\
\hline Time & $(=\mathrm{T})$ & 3 & 4.6103 & 187 & 0.0001 & & \\
\hline Region & $(=R)$ & 1 & 2.4372 & 11.42 & 0.0278 & Feb 94 & Snow Hall = Central Hall \\
\hline $\mathrm{T} \times \mathrm{R}$ & & 3 & 0.1628 & 6.61 & 0.0069 & May 94 & Snow Hall < Central Hall \\
\hline Site (R) & $(=S)$ & 4 & 0.2133 & 8.71 & 0.0001 & Oct 94 & Snow Hall = Central Hall \\
\hline$T \times S(R)$ & & 12 & 0.0246 & 1.01 & 0.4522 & Feb 95 & Snow Hall < Central Hall \\
\hline Error & & 72 & 0.0245 & & & & \\
\hline
\end{tabular}

small, oval or cylindrical faecal pellets and a few diatoms, such as Nitzschia sp., Navicula sp. and Rhizosalenia sp. Flagellate heterotrophs were also present, but they were not identified. Pollen grains were occasionally found in traps from both regions.

The major proportion (78 to $93 \%$ ) of TPM collected by sediment traps in both regions was inorganic (Fig. 4). The fraction of POC was, consequently, quite low, varying between 1.6 and $3.4 \%$ (Fig. 4). The relative contents of both POC and PIM were rather similar among sites, and the extent and the direction of the differences observed between Central Hall and Snow Hall varied through time without any consistent trend (Fig. 4, Table 3). In contrast, the POC:chl a ratios were significantly lower in Central Hall than in Snow Hall throughout the investigation (Fig. 4, Table 3). This ratio estimates the relative content in plant pigments of organic detritus, and values lower than 100 indicate that the carbon originates primarily from phytoplankton (Zeitzschel 1970). The POC:chl a ratios of sedi- 


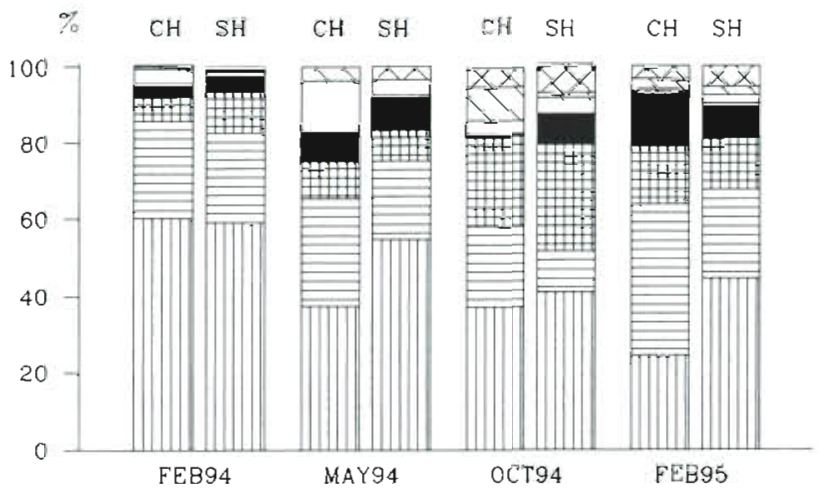

menting particulate material measured in Grotta Azzurra cave were always higher than 600 and reached values up to 3100 in Snow Hall (Fig. 4), suggesting a contribution from autochthonous sources of $\mathrm{POC}$ in addition to open sea phytoplanktonic production.

The total amount of food material sedimenting to the bottom of the cave was calculated as the sum of $\mathrm{TCH}$, TPR and TLI (Fichez 1991b, Navarro et al. 1993) and converted into energy equivalents using the coefficients of $4.1,5.65$ and $9.45 \mathrm{kcal} \mathrm{g}^{-1}$ respectively for the above 3 components (a broad discussion of the utility
X CHARCOAL, FRAGMENTS

$\triangle 9$ ALGAL DEBRIS

LARVAE \& JUVENILES

POSIDONIA DEBRIS

\#賏 INORGANIC DETRITUS:

FAECAL PELLETS

III] AMORPHOUS AGCREGATES
Fig. 3. Mean percentage composition of sedimented coarse material (CM) collecled by sediment traps in Central Hall $(\mathrm{CH})$ and in Snow Hall (SH) during February, May and October 1994 and February 1995. Data are means of 3 replicated sites

and limits of such conversion factors may be found in Fichez 1991 b). The inputs to benthic organisms of both food material and energy were highly variable among sites (Fig. 5, Table 2). Significant differences among regions were also detected in May 1994 and February 1995 (Table 2). Overall, the quantity of food material varied from 79 to $335 \mathrm{mg} \mathrm{m}^{-2} \mathrm{~d}^{-1}$ and represented from 1.6 to $3.9 \%$ of TPM (Fig. 4), probably due to heavy dilution with inorganic particles.

The quality of food material, i.e. the ratios between the different biochemical compounds of trapped organic material (POC, PON, $\mathrm{TCH}_{1} \mathrm{TPR}, \mathrm{TLI}$ ), was
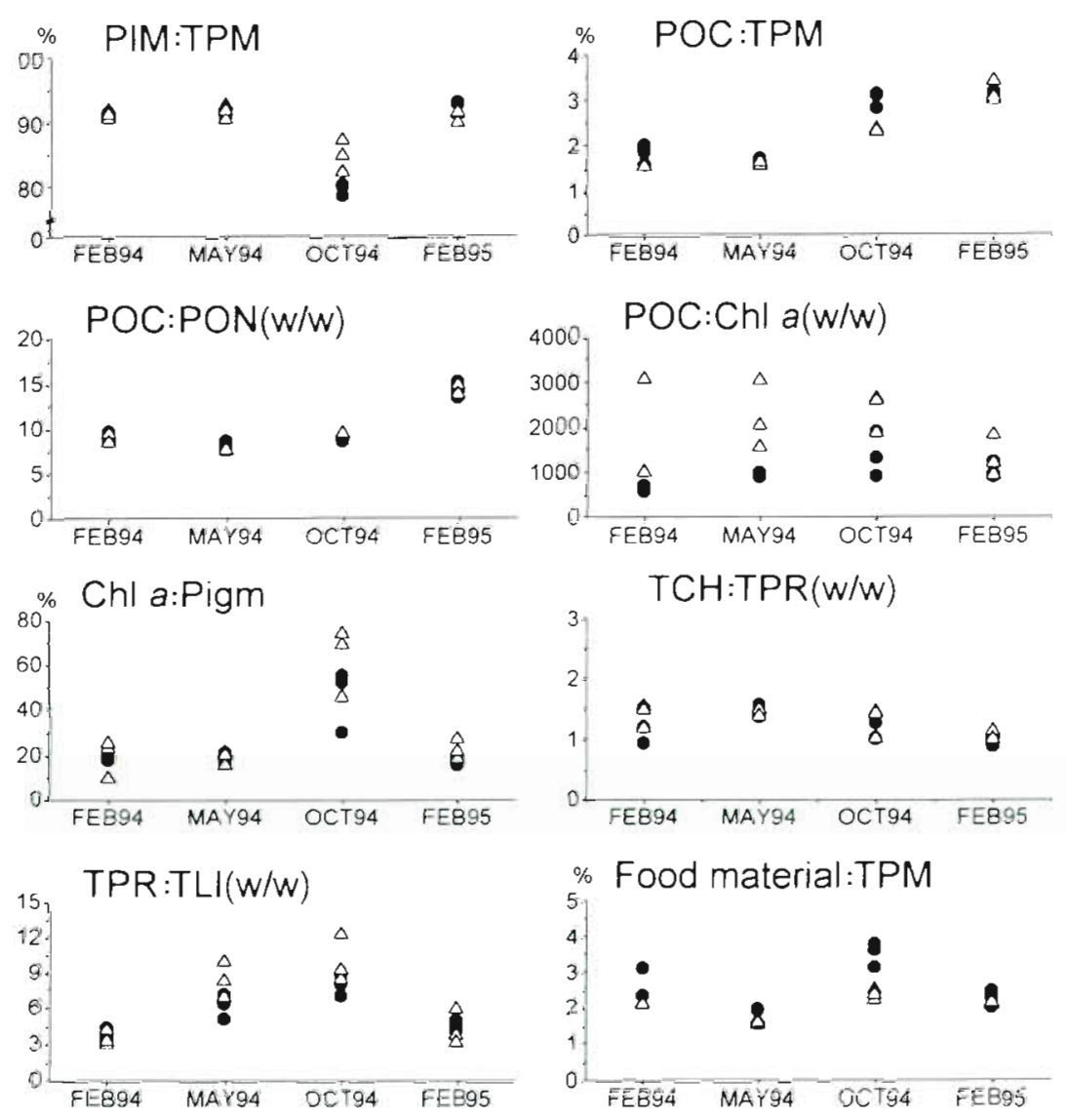

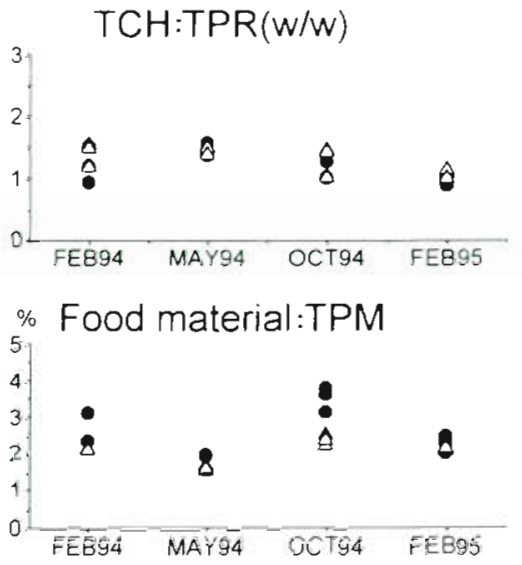

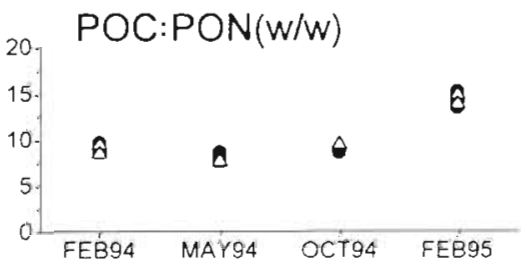

- Central Hall

$\triangle$ Snow Hall

Fig. 4. PIM:TPM ratio (\%), POC:TPM ratio $(\%)$, POC: $P O N$ ratio $(w / w), P O C$ chl a ratio (w/w), chl a:total chloropigments (pigm) ratio $(\%)$, TCH:TPR ratio (w/w), TPR:TLI ratio $(\mathrm{w} / \mathrm{w})$ and food material:TPM ratio $(\%)$ measured in different regions (Central Hall vs Snow Hall) of Grotta Azzurra cave during February, May and October 1994 and February 1995. Three random sites were replicated for each position. Data are means over 4 replicates. Standard deviations were omitted for graphical clarity 
rather constant at the spatial and temporal scales investigated (Fig. 4), although significant differences between regions were found for POC:PON ratios in May and October 1994 and for TPR:TLI ratios in Octo- ber 1994 (Table 3). The POC:PON (w/w) ratios were low during February, May and October 1994, when they varied from a minimum value of 7.6 to a maximum of 9.8 (Fig. 4): this indicates the sedimentation of fresh

Table 3. ANOVA table showing the effects of Time (Feb 94 vs May 94 vs Oct 94 vs Feb 95), Region (Snow Hall vs Central Hali) and Site on the PIM:TPM ratio (\%), POC:TPM ratio (\%), POC:PON ratio (w/w), POC:chl a ratio (w/w), chl a:pigm ratio (\%), TCH:TPR ratıo $(w / w)$ and TPR:TLI ratio $(w / w)$ characterising sedimented particulate material in Grotta Azzurra cave. Time and Region are fixed factors while Site represents a random variable nested in Region. All data were log transformed. Variances were homogeneous after Cochran's C-test. Significant $p$ values $(p<0.05)$ are shown in bold type

\begin{tabular}{|c|c|c|c|c|c|c|c|}
\hline \multicolumn{2}{|c|}{ Source of variation } & \multirow{3}{*}{$\begin{array}{r}\text { df } \\
3\end{array}$} & \multirow{3}{*}{$\begin{array}{c}\text { MS } \\
0.07122\end{array}$} & \multirow{3}{*}{$\begin{array}{c}F \\
127.18\end{array}$} & \multirow{3}{*}{$\begin{array}{c}\mathrm{p} \\
0.0001\end{array}$} & \multicolumn{2}{|c|}{ SNK test } \\
\hline PIM:TPM & & & & & & Time & Region \\
\hline Time & $(=T)$ & & & & & & \\
\hline Region & $(=\mathrm{R})$ & 1 & 0.00294 & 2.69 & 0.1761 & Feb 94 & Snow Hall = Central Hall \\
\hline$T \times R$ & & 3 & 0.00794 & 14.18 & 0.0003 & May 94 & Snow Hall = Central Hall \\
\hline Site (R) & $(=\mathrm{S})$ & 4 & 0.00109 & 1.24 & 0.302 & $\operatorname{Oct} 94$ & Snow Hall $>$ Central Hall \\
\hline $\mathrm{T} \times \mathrm{S}(\mathrm{R})$ & & 12 & 0.00056 & 0.64 & 0.801 & Feb 95 & Snow Hall < Central Hall \\
\hline Error & & 72 & 0.00088 & & & & \\
\hline POC:TPM & & & & & & Time & Region \\
\hline Time & $(=\mathrm{T})$ & 3 & 2.2714 & 335.06 & 0.0001 & & \\
\hline Region & $(=\mathrm{R})$ & 1 & 0.3806 & 38.52 & 0.0034 & Feb 94 & Snow Hall < Central Hall \\
\hline$T \times R$ & & 3 & 0.0924 & 13.64 & 0.0004 & May 94 & Snow Hall = Central Hall \\
\hline Site (R) & $(=\mathrm{S})$ & 4 & 0.0098 & 0.44 & 0.777 & Oct 94 & Snow Hall < Central Hall \\
\hline$T \times S(R)$ & & 12 & 0.0067 & 0.3 & 0.986 & Feb 95 & Snow Hall = Central Hall \\
\hline Error & & 72 & 0.0223 & & & & \\
\hline POC:PON & & & & & & Time & Region \\
\hline Time & $(=\mathrm{T})$ & 3 & 1.6415 & 236.82 & 0.0001 & & \\
\hline Region & $(=\mathrm{R})$ & 1 & 0.0000 & 0.00 & 0.961 & Feb 94 & Snow Hall = Central Hall \\
\hline $\mathrm{T} \times \mathrm{R}$ & & 3 & 0.0271 & 3.91 & 0.037 & May 94 & Snow Hall < Central Hall \\
\hline Site $(R)$ & $(=S)$ & 4 & 0.0156 & 1.21 & 0.313 & Oct 94 & Snow Hall > Central Hall \\
\hline$T \times S(R)$ & & 12 & 0.0069 & 0.54 & 0.883 & Feb 95 & Snow Hall = Central Hall \\
\hline Error & & 72 & 0.0129 & & & & \\
\hline \multicolumn{8}{|l|}{ POC:chl a } \\
\hline Time & $(=\uparrow)$ & 3 & 1.5891 & 4.17 & 0.031 & & \\
\hline Region & $(=\mathrm{R})$ & 1 & 6.9011 & 56.05 & 0.002 & \multicolumn{2}{|c|}{ No alternatives to $H_{0}$ could be specified } \\
\hline$T \times R$ & & 3 & 0.3744 & 0.98 & 0.433 & & \\
\hline Site (R) & $(=\mathrm{S})$ & 4 & 0.1231 & 0.5 & 0.738 & & \\
\hline$T \times S(R)$ & & 12 & 0.3812 & 1.54 & 0.13 & & \\
\hline Error & & 72 & 0.2477 & & & & \\
\hline \multicolumn{8}{|l|}{ Chl a:pigm } \\
\hline Time & $(=\mathrm{T})$ & 3 & 6.568 & 16.39 & 0.0002 & & \\
\hline Region & $(=R)$ & 1 & 0.3218 & 2.39 & 0.197 & \multirow{2}{*}{\multicolumn{2}{|c|}{ No alternatives to $H_{10}$ could be specified }} \\
\hline$T \times R$ & & 3 & 0.3067 & 0.77 & 0.535 & & \\
\hline Site (R) & $(=\mathrm{S})$ & 4 & 0.5378 & 0.7 & 0.594 & & \\
\hline$T \times S(R)$ & & 12 & 0.4007 & 2.09 & 0.028 & & \\
\hline Error & & 72 & 0.192 & & & & \\
\hline TCH:TPR & & & & & & Time & \\
\hline Time & $(=\mathrm{T})$ & 3 & 0.4948 & 6.43 & 0.008 & & \\
\hline Region & $(=\mathrm{R})$ & 1 & 0.1845 & 4.67 & 0.097 & May 94 & $4=$ Oct $94=$ Feb 95 \\
\hline$T \times R$ & & 3 & 0.0276 & 0.36 & 0.784 & & \\
\hline Site $(R)$ & $(=\mathrm{S})$ & 4 & 0.0395 & 0.49 & 0.743 & & \\
\hline$T \times S(R)$ & & 12 & 0.077 & 0.96 & 0.498 & & \\
\hline Error & & 72 & 0.0806 & & & & \\
\hline TPR:TLI & & & & & & Time & Region \\
\hline Time & $(=T)$ & 3 & 4.2734 & 32.66 & 0.0001 & & \\
\hline Region & $(=\mathrm{R})$ & 1. & 0.4744 & 9.45 & 0.0371 & Feb 94 & Snow Hall = Central Hall \\
\hline$T \times R$ & & 3 & 0.5604 & 4.28 & 0.028 & May 94 & Snow I lall = Central Hall \\
\hline Site (R) & $(=S)$ & 4 & 0.0501 & 0.3 & 0.877 & Oct 94 & Snow Hall > Contral Hall \\
\hline$T \times S(R)$ & & 12 & 0.1308 & 0.78 & 0.669 & Feb 95 & Snow Hall = Central Hall \\
\hline Error & & 72 & 0.1678 & & & & \\
\hline
\end{tabular}




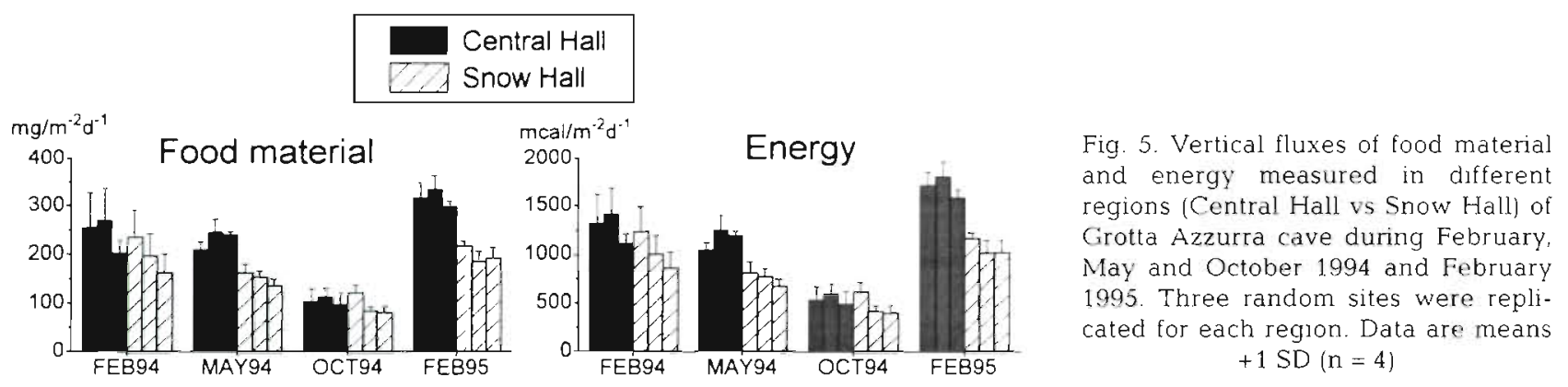

detritus of good nutritional quality (Pocklington \& Leonard 1979, Parsons et al. 1984, Mayzaud et al. 1989, Navarro et al. 1993) Higher values (13.5 to 15.4) were measured in February 1995, implying either low quality, older, nutrient-depleted material or inputs from terrestrial or resuspended particles. Confirmation of the good quality of organic particles sedimenting to the bottom came from the low values of the TCH:TPR ratios measured throughout the investigation (Poulet et al. 1986, Mayzaud et al. 1989), which were always lower than 1.5 .

\section{DISCUSSION}

The composition and vertical fluxes of particulate material in Grotta Azzurra cave were highly heterogeneous. Such spatial variability was particularly evident on a small spatial scale. Significant differences among sites were detected during all the sampling periods for the majority of the compounds that were analysed. Conversely, variations between Central Hall and Snow Hall were not consistent through time; a clear spatial trend emerged only for chloropigments, whose sedimentation rates were consistently higher in Central Hall than in Snow Hall.

Field and laboratory experiments have shown that smooth cylincirical vessels with an inner diameter greater than $45 \mathrm{~mm}$ and an aspect ratio greater than 3 , like those used in the present study, give reliable results both in calm and turbulent hydrodynamic conditions (Gardner 1980a, b, Butman 1986). The high spatial variability observed in Grotta Azzurra cave, therefore, is characteristic of this peculiar environment, and factors other than differences in trapping efficiency of the vessels must account for the observed patterns. The microscopic analysis of $\mathrm{CM}$ has shown that a large fraction of the material sinking to the bottom consists of particles produced by the organisms living on the vault and walls of the cave. Also the large amounts of PIM are probably a consequence of erosive processes of the limestone rock, enhanced by the aggressive action of the sulphurous water (Forti 1989).
This suggests that the sedimentary characteristics of each site might be iniluenced by its location with respect to the vault and the walls of the cave. The role of erosion along rocky walls as a mechanism providing large amounts of detritus has been highlighted by Bavestrello et al. (1991). Moreover, during an investigation along a steep cliff in Balsfjorden, Gulliksen (1982) found that the amount of particulate material sedimenting at a distance of $5 \mathrm{~m}$ from the rocky wall was on average $64 \%$ less than that sedimenting at a distance of $1 \mathrm{~m}$. The variability among fluxes measured at nearby sites might, therefore, reflect local differences of sedimentary environment, depending on the complex geomorphology of the cave.

The scattered accumulations of sediments observable both on the sides and the floor of Grotta Azzurra cave suggests that eddies of the water circulation caused by the irregular shape of the cave and local resuspension of bottom sediments might also contribute to the spatial heterogeneity observed in this system. Patterns of sediment deposition and resuspension, in fact, are dependent on the regime of water circulation, which in submarine caves is largely influenced by the degree of isolation from the open sea and consequently by the geomorphology of the cave. In Snow Hall, patterns of water circulation might be further complicated by the outflowing of sulphurous water from fissures in the floor, which could also produce a turbulent upward transport of particles. Unfortunately the degree of water circulation in Grotta Azzurra cave is still not well known, and further investigations are needed to clarify the potential role of this additional source of variability.

The analysis of the fluxes and the biochemical composition of sedimenting particulate material in Central Hall and in Snow Hall suggests that, in contrast to the heterogeneity observed on a small spatial scale, the overall quantity and quality of sinking particles in distinct regions of Grotta Azzurra cave are less variable than generally indicated for other submarine caves, where progressive impoverishment and degradation of POC have been observed with increasing distance from the entrance (Fichez 1990b, 1991b). With the 
exception of chloropigments, in fact, the differences between Central Hall and Snow Hall were generally small, and no consistent spatial trends were discernible. This result essentially reproduces the patterns observed in the concentration and composition of suspended particulate material (Airoldi \& Cinelli unpubl.), which have been explained as a consequence of autochthonous inputs of fresh POC from local bacterial production in addition to POC advected from outside via water exchanges. Using the POC:chl a ratio as an index of the relative amount of carbon of phytoplanktonic origin and stable isotope ratios as an index of autochthonous bacterial input, the fraction of chemosynthetically derived carbon over the total amount of suspended POC in Snow Hall has been estimated as about $31 \%$ (Southward et al. 1996, Airoldi \& Cinelli unpubl.). In this study, lack of an external reference sediment trap system does not allow direct estimation of the relative contribution of chemosynthesis vs photosynthesis to the vertical fluxes of POC in Grotta Azzurra cave. However, the high values of POC:chl a ratios and the good nutritional quality of food material indicated by the low POC:PON and TCH:TPR ratios (Poulet et al. 1986, Mayzaud et al. 1989) suggest that fresh organic material produced by bacteria in the sulphurous region of the cave reaches the bottom in the form of fast sinking particles. Confirmation comes from the finding of large Beggiatoa-like bacterial filaments in the CM collected both in Snow Hall and in Central Hall.

Oxic-anoxic interfaces have great influence on the vertical fluxes of organic matter (Wassmann 1985). The high stratification and stability of the water column, in fact, may reduce losses of particles from the upper layers to underlying bottom sediments. Flocculation of bacterial material from the vault has often been observed as a consequence of disturbance of the water stratification by divers' bubbles, hence the name Snow Hall given to this inner, sulphur impacted region. Grotta Azzurra cave is of touristic importance and is commonly visited by amateur divers during most of the year Such diving activity presumably has important effects on the whole system and affects fluxes of particulate material. At the moment it is not possible to quantify the impact of diving activity on the overall cycling of carbon in this cave, and further research on this topic is worthwhile.

Fluctuation in the supply of food material is considered one of the major factors affecting the structure, the biomass and the metabolism of benthos (Mills 1975, Graf et al. 1982, Smetacek 1984, Yap 1991). The present results suggest that small-scale spatial variability of fluxes of particulate material is a constant feature of Grotta Azzurra cave, often overriding largerscale patterns between distinct regions in the cave.
This conclusion is consistent with modes of distribution and abundance of benthic organisms (BenedettiCecchi et al. unpubl.). Further research is needed to explore, in more detail, the causes and the ecological significance of this heterogeneity that previous studies on submarine caves have not addressed. Future work should also include investigations on temporal patterns. In the present study, in fact, significant variations of vertical fluxes through different sampling periods were detected, with possible important consequences for the benthic communities. However, no conclusions can be specifically drawn regarding these variations until replication at different temporal scales is included in the experimental design.

Acknowledgements. We thank A. J. Southward and E. C. Southward for stimulating discussions during the work and for comments on a preliminary draft of the manuscript, $L$. Benedetti-Cecchi and A. J. Underwood for suggestions on the experimental design and analysis of data and 2 anonymous referees who greatly improved the quality of the manuscript. We also thank M. Abbiati for help in the field, M. Montresor who aided in the microscopic analyses and I. Niccolai who provided space and facilities at the Marine Environment Research Centre ENEA of La Spezia and her essential assistance in the chemical analyses. This study was funded in part by the EC under MAST programme contract MAS2-CT930058 .

\section{LITERATURE CITED}

Airoldi L, Fabiano M, Cinelli F (1996) Sediment deposition and movement over a turf assemblage in a shallow rocky coastal area of the Ligurian sea. Mar Ecol Prog Ser 133: $241-251$

Akoumianaki l, Hughes JA (1996) Distribution of the macroinfauna along a submarine cave with sulphur watersprings. In: Dando PR (ed) Oxic-anoxic interfaces as productive sites. MAST Contract CT93-0058, Final Rep, Vol I

Alvisi M, Barbieri F, Bruni R. Cinelli F, Colantoni P, Grand GF, Maltoni P (1994) La Grotta Azzurra di Capo Palinuro. Mem Ist Ital Speleologia Ser II 6:51-56

Balduzzi A, Bianchi CN, Boero F, Cattaneo-Vietti R, Pansini $M$, Sarà $M(1989)$ The suspension-feeder communities of a Mediterranean sea cave. Sci Mar 53:387-395

Bavestrello $G$, Cattaneo-Vietti $R$, Danovaro R, Fabiano M (1991) Detritus rolling down a vertical cliff of the Ligurian Sea (Italy): the ecological role in hard bottom communities. PSZN I Mar Ecol 12:281-292

Benedetti-Cecchi L, Airoldi L, Abbiatı M. Cinelli F (1n press) Exploring the causes of spatial variation in an assemblage of benthic invertebrates from a submarine cave with sulphur springs. J Exp Mar Biol Ecol

Biblioni MA, Uriz MJ, Gili JM (1989) Sponge communities in three submarine caves of the Balearic Islands (Western Mediterranean): adaptations and faunistic composition. PSZN I: Mar Ecol 10:314-334

Blight EG, Dyer NJ (1959) A rapid method of total lipid extraction and purification. Can J Biochem Physiol 37:911-917

Bloesch J, Burns NM (1980) A critical review of sedimentation trap technique. Schweiz Z Hydrol 42:15-55

Blomqvist $S$, Håkanson L (1981) A review on sediment traps in aquatic environments. Arch Hydrobiol 91:101-132 
Butman CA (1986) Sediment trap biases in turbulent flow result from a laboratory study. J Mar Res 44:64,5-693

Cinelli F, Fresi E, Mazzella L, Pansini M, Pronzato R, Svoboda A (1977) J)istrubution of benthic phyto- and zoocoenoses along a light gradient in a superficial marine cave of the Sorrentine Peninsula. In: Keegan BF, Leidingh O, Boaden PJS (eds) Biology of benthic organisms. Pergamon Press, London, p 173-184

Dean WE Jr (1974) Determination of carbonate and organic matter in calcareous sediments and sedimentary rocks by loss on ignition: comparison with other methods. J Sedim Petrol 44:242-248

Deuser WG, Ross EH, Anderson RF (1981) Seasonality in the supply of sediment to the deep Sargasso Sea and implications for the rapid transfer of. matter to the deep ocean. Deep Sea Res 28:495-505

Dubois M, Gills KA, Hamilton JK, Roberts PA, Smith F (1956) Colorimetric method for the determination of sugars and related substances. Analyt Chem 28:350-356

Fellows DA, Karl DM, Knauer GA (1981) Large particle fluxes and the vertical transport of living carbon in the upper $1500 \mathrm{~m}$ of the northeast Pacific Ocean. Deep Sea Res $28.921-936$

Fichez R (1990a) Les pigments chlorophylliens: indices d'oligotrophie dans les grottes sous-marines. C R Acad Sci Paris (Sér III) 310:155-161

Fichez R (1990b) Decrease in al.Joch thonous organic inputs in dark submarine caves, connection with lowering in benthic community richness. Hydrobiologia 207:61-69

Fichez R (1991a) Benthic oxigen uptake and carbon cycling under aphotic and resource limiting conditions in a submarine cave. Mar Biol 110:137-143

Fichez R (1991b) Suspended particulate matter in a Mediterranean submarine cave. Mar Biol 108:167-174

Fichez R (1991c) Composition and fate of organic matter in submarine cave sediments; implications for the biogeochemical cycle of organic carbon. Oceanol Acta 14:369-377

Fitzsimons M, Dando PR (1996) Chemical characteristics of the water mass of the Grotta Azzurra (S. Italy): a submarine cave fed by hydrothermal springs. In: Dando PR (ed) Oxic-anoxic interfaces as productive sites. MAST Contract CT93-0058, Final Rep, Vol I

Forti $\mathrm{P}$ (1989) The role of sulfide-sulfate reactions in speleogenesis. Proc 10th Int Speleological Congr, Budapest 1: $71-73$

Fowler SW, Knauer GA (1986) Role of large particles in the transport of elements and organic compounds through the oceanic water column. Prog Oceanogr 16:147-194

Gardner WD (1980a) Sediment trap dynamics and calıbration a laboratory evaluation. J Mar Res 38:17-39

Gardner WD (1980b) Field assessment of sediment traps. J Mar Res 38:4 1.-52

Garrabou J, Flos J (1995) A simple diffusion-sedimentation model to explain planktonic gradients within a NW Mediterranean submarine cave. Mar Ecol Prog Ser 123 : $273-280$

Gili JM, Riera T, Zabala T (1986) Physical and biological gradients in a submarine cave on the Western Mediterranean coast (north-east Spain). Mar Biol 90:291-297

Graf G, Bengtsson W, Diesner U, Schulz R, Theede H (1982) Benthic response to sedimentation of a spring phytoplankton bloom: process and budget. Mar Biol 67:201-208

Gulliksen B (1982) Sedimentation close to a near vertical rocky wall in Balsfjorden, northern Norway. Sarsia 67: $21-27$

Gundersen K, Wassmann P (1990) Use of chloroform in sediment traps: caution advised. Mar Ecol Prog Ser 64:187-195
Harmelin JG, Vacelet J, Vasseur P (1985) Les grottes sousmarines obscures: un milieu extrème et un remarquable biotope refuge. Téthys 11:214-229

Hedges JI, Lee C, Wakeham SG, Hernes PJ, Peterson ML (1993) Effects of poison and preservatives on the fluxes and elemental composition of sediment trap materials. J Mar Res 51:651-668

Hedges JI, Stern JH (1984) Carbon and nitrogen determinations of carbonate containing solids Limnol Oceanogr 29:657-663

Honjo S (1980) Material fluxes and modes of sedimentation in the mesopelagic and bathypelagic zones. J Mar Res 38: $53-97$

ISSD (1994) Grotte manne d'ltalia. Mem Ist. Ital Speleologia Ser 116

Knauer GA, Karl DM, Martin JH, Hunter C (1984) In situ effects of selected preservatives on total carbon, nitrogen and metals collected in sediment traps. J Mar Res 42: $445-462$

Krey I (1964) Die mittlere Tlefenverteilung von Seston Mikrobiomasse und Detritus in nördlichen Nordatlantik. Kieler Meeresforsch 20:18-29

Laborel J, Vacelet J (1959) Les grottes sous-marines obscures en Méditerranée. Cah Océanogr 13:73-107

Lee C, Hedges JI, Wakeham SG, Zhu N (1992) Etfectiveness of various treatments in retarding microbial activity in sediment trap material and their effects on the collection of swimmers. Limnol Oceanogr 37:117-130

Lee C, Wakeham SG (1988) Organic matter in seawater-biogeochemical processes. In: Riley JP (ed) Chemical oceanography, 2nd edn, Vol 9. Academic Press, London, p 1-51

Lowry OH, Rosebrough NJ, Farr AL, Randall RJ (1951) Protein measurement with Folin phenol reagent. J Biol Chem 193:265-275

Marsh BJ, Weinstein DB (1966) Simple charring method for determination of lipids. J Lipid Res 7:574-576

Mattison RG. Abbiati M, Dando PR, Fitzsimons M, Pratt SM, Southward AJ, Southward EC (1996) Microbial ecology of. submarine caves with hydrothermal sulphidic springs at Cape Palınuro, Italy. In: Dando PR (ed) Oxic-anoxic interfaces as productive sites. MAST Contract CT93-0058, Final Rep, Vol II

Mattison RG, Dando PR (1994) Composition of microbial mats from a submarine cave with shallow hydrothermal vents at Capo Palinuro, Southern Italy. Bridge Newslett 7:10-11

Mayzaud P. Chanut JP, Ackman RG (1989) Seasonal changes of the biochemical composition of marine particulate matter with special reference to fatty acids and sterols. Mar Ecol Prog Ser 56:189-204

Mills EL (1975) Benthic organisms and the structure of marine ecosystems. J Fish Res Bd Can 32:1657-1663

Moal J, Samain JF, Le Coz JF, Daniel JY (1.985) Protéines, glucides, lipides particulares: aspects methodologiques Océanis 11:487-502

Navarro JM, Clasing E, Urrutia G, Asencio G, Stead R, Herrera C (1993) Biochemucal composition and nutritive value of suspended particulate matter over a tidal flat of southern Chile. Estuar Coast Shelf Sci 37:59-73

Ott JA, Svoboda A (1976) Sea caves as model systems for energy flow studies in primary hard bottom communities Pubbl Stn Zool Napoli 40:477-485

Palau M. Cornet C. Riera T, Zabala M (1991) Planktonic gradients along a Mediterranean sea cave. Oecologia Aquatica 10:299-316

Parsons TR, Takahashi M. Hargrave B (1984) Biological oceanographic processes, 3rd edn. Pergamon Press, Oxford 
Peinert R, Saure A, Stegmann P, Stienen C, Haardt H, Smetacek $V(1982)$ Dynamics of primary production and sedimentation in a coastal ecosystem. Neth J Sea Res 16:276-289

Pérès JM, Picard J (1949) Notes sommaires sur le peuplement des grottes sous-marines de la région de Marseille. C R Soc Biogéogr 227:42-45

Pfannkuche O (1993) Benthic response to the sedimentation of particulate organic matter at the BIOTRANS station, $47^{\circ} \mathrm{N}, 20^{\circ} \mathrm{W}$. Deep Sea Res 40:135-149

Pocklington R, Leonard JD (1979) Terrigenous organic matter in sediments of the St. Lawrence Estuary and the Saguenay Fjord. J Fish Res Bd Can 36:1250-1255

Poulet SA, Cossa D, Marty JC (1986) Combined analyses of the size spectra and biochemical composition of particles in the St. Lawrence estuary. Mar Ecol Prog Ser 30:205-214

Puskaric S, Fowler SW, Miquel JC (1992) Temporal changes in particulate flux in the Northern Adriatic Sea. Estuar Coast Shelf Sci 35:267-287

Riedl R (1966) Biologie der Meereshöhlen. Paul Parey, Hamburg

Smetacek V (1984) The supply of food to the benthos. In: Fasham MJR (ed) Flows of energy and materials in marine ecosystems. Theory and practice. Plenum Press, New York, p 517-547

Southward AJ, Kennicutt MC, Alcalà-Herrera J, Abbiati M, Airoldi L, Cinelli F, Bianchi CN, Morri C, Southward EC (1996) On the biology of submarine caves with sulphur springs: appraisal of ${ }^{13} \mathrm{C},{ }^{2} \mathrm{C}$ ratios as a guide to trophic relations. J Mar Biol Ass UK 76:265-285

Stewart JG (1983) Fluctuations in the quantity of sediment trapped among algal thalli on intertidal rock platforms in southern California. J Exp Miar Biol Ecol 73:205-211

Strickland JDH, Parsons TR (1972) A practical handbook of seawater analysis. Bull Fish Res Bd Can 167

This article was presented by S. W. Fowler (Senlor Editorial Advisory, Monaco
Stuben D, Winckler G, Bayer R, Braun S, Sedwick P, Colantoni $P$ (1996) Shallow submarine geothermal sites in caves of Capo Palinuro (Italy). In: Dando PR (ed) Oxic-anoxic interfaces as productive sites. MAST Contract CT93-0058. Final Rep, Vol II

True MA (1970) Etude quantitative de quatre peuplements shiaphiles sur substrat rocheux dans la région marseillase. Bull lnst Océanogr Monaco 69:1-48

Underwood A.J (1981) Techniques of analysis of variance in experimental marine biology and ecology. Oceanogr Mar Biol A Rev 19:513-605

Vacelet J, Boury-Esnault N, Harmelin JG (1994) Hexactinellid Cave, a unique deep-sea habitat in the scuba zone. Deep Sea Res 41:965-973

Valiela I (1984) Marine ecological processes. Springer-Verlag, New York

Wassmann P (1985) Sedımentation of particulate material in two shallow, land-locked fjords in western Norway. Sarsia $70: 317-331$

Wassmann P (1991) Dynamics of primary production and sedimentation in shallow fjords and polls of western Norway. Oceanogr Mar Biol A Rev 29:87-154

Winer BJ (1971) Statistical principles in experimenta] designs, 2nd edn. McGraw-Hill Kogakusha, Tokyo

Yap HT (1991) Benthic energy dynamics in a southern Baltic ecosystem. Mar Biol 108:477-484

Zabala M, Riera T, Cili JM, Barange M, Lobo A, Peñuelas J (1989) Water flow, trophic depletion, and benthic macrofauna impoverishment in a submarine cave from the western Mediterranean. PSZN I: Mar Ecol 10: $271-287$

Zeitzschel B (1970) The quantity, composition and distrybution of suspended partıculate material in the Gulf of California. Mar B1ol 7:305-318

Manuscript first recelved: December 14, 1995

Revised version accepted: April 10, 1996 